УДК 378.091.33 - 027.22: 004.77

Рамський Юрій Савіянович

доктор педагогічних наук, професор, завідувач кафедри інформаційних технологій і програмування Національний педагогічний університет імені М.П. Драгоманова, м. Київ, Україна

ORCID ID 0000-0003-2296-0654

y.s.ramsky@npu.edu.ua

Твердохліб Ігор Анатолійович

кандидат педагогічних наук, доцент кафедри інформаційних технологій і програмування

Національний педагогічний університет імені М.П. Драгоманова, м. Київ, Україна

ORCID ID 0000-0001-6301-0159

i.a.tverdokhlib@npu.edu.ua

Ящик Олександр Богданович

кандидат педагогічних наук, доцент кафедри комп'ютерних технологій

Тернопільський національний педагогічний університет імені Володимира Гнатюка,

м. Тернопіль, Україна

ORCID ID 0000-0002-8420-3336

SanyTNPU@tnpu.edu.ua

Рамський Андрій Юрійович

доктор економічних наук, професор, професор кафедри фінансів та економіки

Київський університет імені Бориса Грінченка, м. Київ, Україна

ORCID ID 0000-0001-7368-697X

a.ramskyi@kubg.edu.ua

\title{
ВИКОРИСТАННЯ ВІДКРИТИХ ОНЛАЙН КУРСІВ В УМОВАХ ЗМШШАНОГО НАВЧАННЯ МАЙБУТНІХ ФАХІВЦІВ 3 ІНФОРМАЦІЙНИХ ТЕХНОЛОГІЙ
}

\begin{abstract}
Анотація. У роботі розглянуто методику використання масових відкритих онлайн курсів (MOOC) під час підготовки майбутніх фахівців 3 інформаційних технологій, доведено важливість залучення студентів до використання відкритих онлайн курсів для самоосвіти та саморозвитку. Використання МООС у навчальній діяльності студентів інформатичних спеціальностей дає змогу їм постійно оновлювати свої знання в епоху швидкозмінних інформаційних технологій, удосконалювати свої вміння та навички з фахових дисциплін, i, зрештою, «пройти» курси, що розроблені викладачами провідних університетів світу. У межах дослідження було проведено порівняльний аналіз найпопулярніших МООСплатформ, здійснено добір онлайн курсів, які доцільно було б використовувати при вивченні студентами дисциплін «Webтехнології та wеbдизайн» i «Webпрограмування». Розроблено модель інтеграції МООС у структуру класичної навчальної дисципліни (описано способи використання МООС під час виконання лабораторних, індивідуальних робіт, під час самостійної роботи студентів, підготовки до модульного чи підсумкового контролю), яка може використовуватись не лише для підготовки студентів, що навчаються за спеціальностями галузі знань 12 «ннформаційні технології», а й для студентів інших закладів вищої освіти України з врахуванням теоретичних основ і практичного досвіду організації дистанційного та змішаного навчання. На основі запропонованої моделі інтеграції описано методику використання МООС під час фахової підготовки майбутніх ITфахівців, методику організації та проведення педагогічного дослідження та наведено його результати. Під час проведеного дослідження було з'ясовано, що педагогічно виважене впровадження в навчальний процес МООС сприяє формуванню у студентів навичок самоосвіти, вдосконаленню та поглибленню фахових компетентностей, відкриває перед ними альтернативні шляхи здобуття вищої освіти.
\end{abstract}

Ключові слова: дистанційне навчання; змішане навчання; масові відкриті онлайн курси; інформаційні технології. 


\section{1. ВСТУП}

Постановка проблеми. Освіта в XXI ст. стала одним з найважливіших факторів, що впливають на розвиток країн, оскільки сучасне суспільство базується на знаннях, які, своєю чергою, спричиняють різке підвищення ролі людського фактора, спроможності фахівця ефективно діяти відповідно до нових умов. Щоб вдало реалізувати себе на ринку праці, умова наявності вищої освіти вже не $є$ визначальною. Загалом сучасний фахівець повинен володіти низкою психічних властивостей, професійними вміннями і навичками, використовуючи які, він міг би розв'язувати нестандартні і нетипові задачі, гнучко пристосовуватись до несподіваних ситуацій, раціонально, творчо, самостійно вирішувати найрізноманітніші життєві і професійні проблеми, які можуть виникнути, генерувати нові ідеї, вільно володіти новітніми технологіями.

Державна стратегія розвитку вищої освіти України, що визначається Законами України «Про освіту», «Про вищу освіту», «Про наукову i науково-технічну діяльність», Положенням про дистанційне навчання, Положенням про електронні освітні ресурси, Стратегією розвитку вищої освіти України на 2021 - 2031 роки, передбачає розбудову нової системи вищої освіти, що буде зорієнтована на підготовку висококваліфікованого працівника, здатного орієнтуватись у глобальних змінах сучасного суспільства та економіки, постійного розвитку нових інформаційних технологій, підготовку випускника, який буде володіти системою професійних, загальних та інформатичних компетентностей, що дадуть йому змогу постійно розвиватися, самовдосконалюватися, навчатися протягом усього життя.

Особливе місце в професійній діяльності фахівців з інформаційних технологій займають навички самостійного здобуття нових знань, умінь та навичок, самоорганізації та постійного підвищення своєї кваліфікації, оскільки інформаційні технології перебувають у постійному розвитку: кожен рік зростає ступінь інтеграції мікросхем, з'являються нові технологічні вирішення апаратного забезпечення цифрових пристроїв, нові технології (активно розвиваються робото-технічні системи, системи штучного інтелекту, Internet of Things, 3-D друк тощо), відбувається «старіння» одних мов програмування і створення нових, оновлюються та створюються нові бібліотеки до них, і це не говорячи вже про постійне вдосконалення програмного забезпечення, появу нових функцій та можливостей їх використання. А тому «старіння» знань у сфері інформаційних технологій відбувається в кілька разів швидше, ніж в інших наукових та професійних галузях.

Тому виникає гостра необхідність у підготовці конкурентоспроможного фахівця 3 інформаційних технологій, здатного орієнтуватися в мінливому інформаційному суспільстві та спроможного до самонавчання. Для цього необхідно, перш за все, забезпечити формування в майбутніх IT-фахівців знань 3 теоретичних основ їх функціонування, загальних (уміння вчитися, спілкуватися іноземною мовою, працювати в умовах невизначеності, планувати своє навантаження та ефективно розподіляти роботу, підтримувати високу працездатність тощо) та фахових (уміння швидко та легко оволодівати новими інформаційними технологіями, застосовувати нові стандарти в галузі інформаційних систем та технологій, опрацьовувати та відбирати потрібні дані серед наявного інформаційного колапсу в глобальній мережі, формувати нові конкурентоспроможні ідеї й реалізовувати їх у проєктах, розробляти бізнесрішення та оцінювати нові технологічні пропозиції та ін.) компетентностей.

Так, одним із шляхів, що забезпечують вирішення проблеми підготовки фахівця 3 інформаційних технологій, який уміє швидко оволодівати новими знаннями та інформаційними технологіями, здатен навчатися протягом усього життя, $\epsilon$ 
використання масових відкритих онлайн курсів (від англ. Massive Open Online Courses - MOOC) під час навчання в закладі вищої освіти та в подальшій професійній діяльності. На нашу думку, педагогічно виважене впровадження МООС у навчальний процес сприятиме ознайомленню студентів інформатичних спеціальностей 3 можливостями використання МООС, розширить їх уявлення про доступність вивчення інформаційних технологій 3 використанням курсів відомих університетів світу, формуватиме навички самоосвіти та саморозвитку.

Аналіз останніх досліджень і публікацій. Оскільки дистанційна освіта та масові відкриті онлайн (дистанційні) курси - два тісно пов'язані поняття, то проведемо короткий аналіз досліджень 3 даної проблематики. Так, теоретичними та практичними питаннями впровадження технологій дистанційного навчання займались українські (О.О. Андрєєв, В.Ю. Биков, .Л. Бугайчук, О.П. Буйницька, В.В. Бондаренко, Л.О. Варченко-Троценко, В.М. Кухаренко, Н.В. Морзе, Н.Г. Сиротенко) та закордонні (Terry Anderson, Cornelia M. Ashby, Michael G. Moore, Charles A. Wedemeyer) вчені.

Вагомий внесок у дослідження теоретичних та практичних аспектів впровадження МООС у навчальний процес вищої школи зробили І.В. Бацуровська, К.Л. Бугайчук, В.М. Кухаренко, В.П. Олексюк, І.О Примаченко, О.А. Самойленко, О.В. Струтинська, М.А. Умрик та інші. Серед закордонних дослідників варто виокремити Н.В. Тихомирову, Lori Breslow, Dave Cormier, George Siemens, J. Selingo, Dhawal Shah.

В.М. Кухаренко та К.Л. Бугайчук у роботах [1], [2], [3] М. М. Березицький та В.П. Олексюк [4], І.В. Бацуровська [5], [6] описують зміст поняття «масові відкриті дистанційні курси», проводять дослідження структури МООС різних типів та особливостей їх реалізації. У їх дослідженнях досить ретельно розглянуто педагогічні та організаційні особливості організації світових платформ МООС та український досвід у цій сфері. У роботах [1], [3] та [7] проведено історичний аналіз становлення та розвитку МООС у світі.

Н.В. Морзе, О.П. Буйницька, Л.О. Варченко-Троценко в навчальному посібнику [8] розглядають традиції та інновації сучасної освіти, проводять огляд масових відкритих онлайн курсів як складової системи відкритої освіти. О.А. Самойленко [9] проведено огляд освітніх онлайн платформ, їх змістового наповнення та доступності.

Досить велика кількість наукових робіт щодо питань впровадження МООС у навчальний процес закладів вищої освіти міститься в працях закордонних учених. Зокрема в роботі [10] проведено огляд літературних джерел з MOОС. А.A. Aldahdouh, A.J. Osório в [11] та A. McAuley, B. Stewart, G. Siemens, D. Cormier в [12] розглядають теоретичні та практичні аспектам використання МООС у вищій освіті. У роботах [13], [14], [15] наводяться переважно порівняльні характеристики використання відкритих онлайн курсів, статистичні дані щодо розподілу курсів між науковими галузями, кількості слухачів, зареєстрованих на курс, порівнюються відсоткові відношення тих, хто завершив курс, хто пройшов його частково, і тих, хто просто записався на курс без активної діяльності.

D. Andone, V. Mihaescu [16] описують досвід впровадження МООС у систему класичних навчальних курсів закладів вищої освіти, аналізують можливість використання засобів онлайн навчання та їх вплив на формування професійних компетентностей. M.J. Israel в роботі [17] аналізує можливі шляхи використання МООС в умовах організації змішаного навчання, наводить висновки щодо ефективності результатів навчання з використанням МООС та його вплив на студентів та викладачів. A. Bralić, B. Divjak в [18] наводять результати експериментального дослідження 3 використання МООС при вивченні студентами навчальної дисципліни «Дискретна математика і теорія графів» при підготовці студентів спеціальності «Інформаційні 
технології та програмна інженерія» в Загребському університеті. У цій роботі досить детально розглядаються результати анкетування студентів і наводяться статистичні дані проведеного експерименту, проте методика організації навчання з використанням MOOC та схема інтеграції в структуру начальної дисципліни не описана. Відсутні також рекомендації щодо використання МООС при вивченні студентами дисциплін циклу «програмування».

3 початку 2000-х років в Україні активно проводилися дослідження 3 теоретичних, практичних та методичних основ впровадження дистанційної освіти у заклади вищої освіти. Проте 3 появою в світовому освітньому середовищі МООС з'явилися дослідження українських науковців щодо теоретичних та методичних аспектів впровадження масових відкритих онлайн курсів у заклади вищої освіти України. Надалі кількість досліджень з даної тематики невпинно зростала. Зокрема варто виокремити ряд досліджень, у яких досліджується з питань інтеграції МООС у класичні навчальні дисципліни (навчальні дисципліни що вивчаються в очній формі шляхом проведення лекційних, лабораторних, семінарських, практичних, індивідуальних занять):

- Аналіз можливостей використання МООС при підготовці інженерівпрограмістів та інженерів-викладачів, порівняння МООС 3 вивчення алгоритмів проведено Л.А. Ібрагімовою в роботі [19].

- О.В. Струтинська та М.А. Умрик у працях [20], [21] досліджують можливості використання технології МООС для підготовки майбутніх учителів інформатики. У їх роботах проведено аналіз сучасного стану впровадження масових відкритих онлайн курсів в Україні, наведено переваги та недоліки застосування МООС під час підготовки майбутніх учителів інформатики.

Отже, в описаних вище наукових дослідженнях частково розглядаються питання впровадження МООС у систему вищої освіти України, проте не вказано, у який спосіб MOOC мають впроваджуватись у систему освіти в межах чинного законодавства та як саме їх інтегрувати в структуру вивчення навчальних дисциплін підготовки фахівців певної спеціальності.

Метою дослідження $є$ обгрунтування необхідності використання MOOC у навчальному процесі закладів вищої освіти України, розроблення та опис окремих компонентів методики використання МООС при організації змішаного навчання студентів галузі знань 12 «нфформаційні технології» в умовах змішаного навчання.

\section{2. МЕТОДИКА ДОСЛІДЖЕННЯ}

Дослідження проводилось на базі факультету інформатики Національного педагогічного університету імені Михайла Драгоманова. Експериментальне дослідження полягало в залученні студентів інформатичних спеціальностей, зокрема студентів різних спеціальностей галузі знань 12 «Інформаційні технології» до використання масових відкритих онлайн курсів при вивченні фахових дисциплін в умовах змішаного навчання.

Для досягнення поставленої в роботі мети було проведено аналіз нормативних та методичних документів у сфері освіти, освітніх стандартів підготовки фахівців 3 інформаційних технологій; визначено їх типи, переваги та недоліки використання; 3'ясовано зміст поняття «масовий відкритий онлайн курс», здійснено огляд наукових публікацій українських та закордонних вчених щодо питань методики вивчення та впровадження в навчальний процес МООС. Під час дослідження було використано теоретичні (аналіз літературних джерел та нормативних документів, порівняння думок учених щодо використання МООС при навчанні студентів, узагальнення i 
систематизація теоретичного матеріалу 3 проблеми дослідження) та емпіричні (анкетування студентів, бесіди зі студентами та викладачами, аналіз результатів експериментального дослідження) методи.

\section{3. РЕЗУЛЬТАТИ ДОСЛІДЖЕННЯ}

Сучасному інформаційному суспільству характерне інтенсивне i масове впровадження нових технологій у всі сфери життєдіяльності. Дедалі глибше проникають у виробництво, сферу обслуговування та розваги, робото-технічні системи, у суспільний побут та організацію функціонування житлових приміщень - технології Інтернету речей, активно розвиваються та впроваджуються системи штучного інтелекту та експертні системи. Не оминають стороною процеси глобалізації та інформатизації і систему освіти. Серед сучасних освітніх трендів можна виокремити такі, як-от: використання сучасних педагогічних технологій та персоналізації навчання, технологій дистанційного навчання, хмарних технологій, мобільного навчання та МООС. Вони впливають не тільки на зміст освіти та їі якість, але й визначають певною мірою добір методів, засобів і форм організації навчальної діяльності.

У даному дослідженні під дистанційним навчанням будемо розуміти форму організації навчального процесу, відповідно до якої всі учасники навчально-виховного процесу перебувають територіально в різних місцях (перебування об'єкта та суб'єкта навчання в межах однієї лабораторії та їх взаємодія віч-на-віч неможливі), а організація навчального процесу відбувається 3 використанням інформаційно-комунікаційних технологій. Водночас взаємодія та комунікація учасників може відбуватись у синхронному (Інтернет-конференції, чати) та асинхронному (CMS-системи) форматах.

Змішане навчання - це форма організації навчальної діяльності з використанням як традиційних (лекції, практичні чи семінарські заняття, лабораторні роботи тощо), так і дистанційних форм організації навчального процесу (поєднання очного та електронного навчання).

Однією з найновіших форм організації дистанційного навчання, що активно використовується у світовому освітньому просторі, є масові відкриті онлайн курси розміщені в мережі Інтернет навчальні курси 3 вільним доступом до них, яким притаманні дві ключові риси: відкритий доступ та масовість. Відкритий доступ передбачає безкоштовність курсу та його відкритість для доступу, а масовість - участь у проходженні курсу великої кількості учасників з усього світу.

MOOC з'явились не спонтанно, а $\epsilon$ логічним розвитком відкритих освітніх ресурсів i дистанційного навчання [8]. Уперше термін МООС [1], [22] був запропонований у 2008 році Браяном Олександром і Дейвом Кормье під час навчання на першому відкритому онлайн курсі «Connectivism and Connective Knowledge» [4], [12], який проводили Джордж Сіменс і Стівен Даунс. У наступні роки ідея створення та використання масових відкритих курсів здобула неабияку популярність не тільки як форма організації дистанційного навчання, але і як спосіб швидкого і вільного доступу студентів до матеріалів навчальних дисциплін під час навчання в університеті, засіб для набуття нових знань, умінь та навичок, розвитку та самоосвіти абсолютно всіх верств населення, що мають доступ до глобальної мережі.

Оскільки перші МООС були орієнтовані лише на студентів, то більшістю їх учасників є молодь. 3 одного боку, вільний доступ до МООС дає змогу пройти навчання на курсах провідних університетів та викладачів світу, а з іншого боку відкриває широкі можливості доступу до якісної та зручної форми здобування освіти для людей, які не мають можливості повноцінно навчатись через певні проблеми зі здоров'ям, географічні, часові, фінансові чи процедурні обмеження. 
Дистанційний навчальний курс - це комплекс логічно структурованих навчальнометодичних матеріалів, призначених для організації індивідуального та групового навчання 3 використанням технологій дистанційного навчання (переважно 3 використанням CMS чи LMS-систем). Доступ до дистанційного навчального курсу забезпечується засобами ІКТ 3 використанням мережі Інтернет, а «взаємодія» 3 викладачем (чи тьютором) відбувається зазвичай в асинхронному режимі.

Відмінністю МООС від дистанційних навчальних курсів $\epsilon$ автоматизація навчання на них, оскільки при збільшенні кількості студентів не потрібно збільшувати штат працівників університету. Велика частина запитань, що виникають у процесі проходження курсу, може вирішуватись у чатах, соціальних мережах на форумах, оскільки МООС залучає слухачів, які в процесі навчання самоорганізуються для досягнення відповідних цілей, рівня знань і навичок, а також за спільними інтересами. Масові відкриті онлайн курси зазвичай містять відеоуроки, теоретичний матеріал поданий засобами вебтехнологій, завдання із зворотнім зв'язком та форуми, використання яких дає змогу слухачам курсів взаємодіяти з викладачами та між собою.

Про важливе місце в системі освіти масових відкритих онлайн курсів наочно «говорить» статистика постійного збільшення їх кількості на світових МOOCплатформах. На рис. 1 наведено динаміку зміни кількості відкритих онлайн курсів 3 2012 по 2020 роки за даними ресурсу Class Central [23].

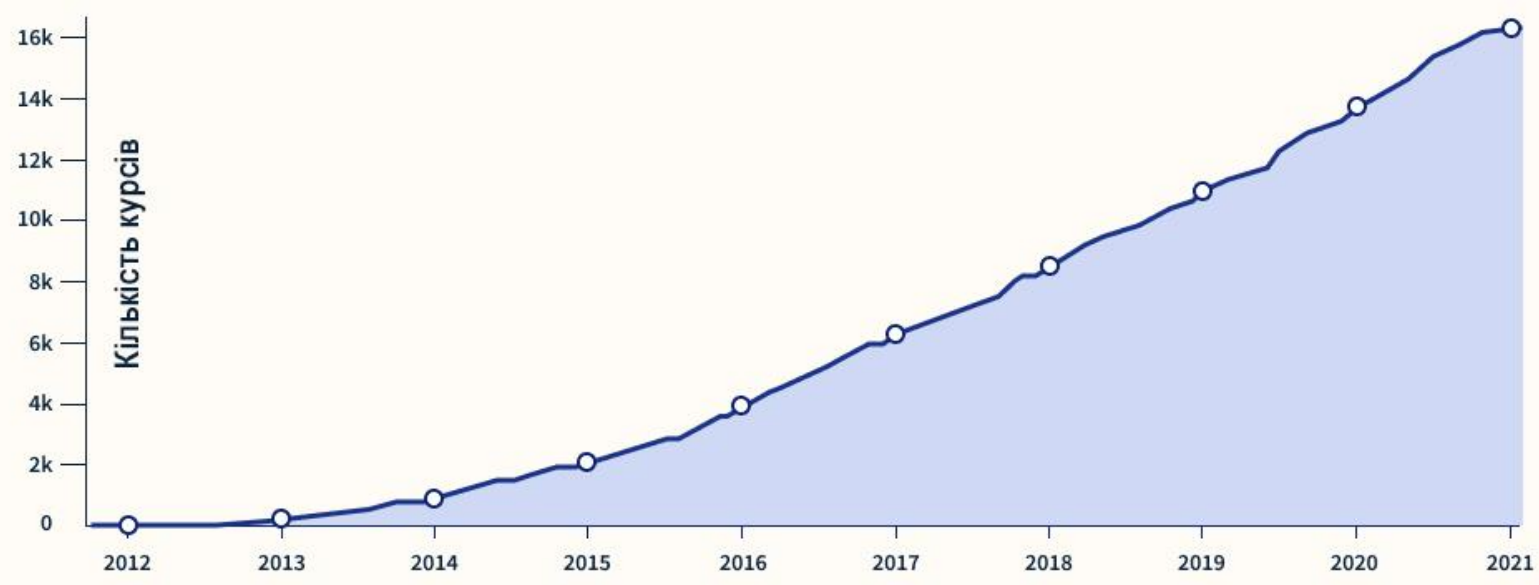

Рис. 1. Динаміка зміни кількості МООС

У системі освіти Україні наразі дистанційна вища і середня освіта в повному обсязі не реалізовані, оскільки відсутня нормативно-правова база для повноцінного впровадження дистанційного навчання. Проте впродовж останніх $10-12$ років у більшості закладів вищої освіти України існують реальні спроби впровадження дистанційних технологій навчання, використання відкритих (у вільному доступі) чи закритих (доступних лише для студентів одного вищого навчального закладу) онлайн ресурсів. Відповідно не існує і єдиного підходу щодо моделі впровадження та методики організації такого навчання, зокрема закріплених на законодавчому рівнях.

Про важливість дистанційної форми здобуття вищої освіти говорить той факт, що в деяких країнах Європи та Азії до 30 \% студентів вже здобувають вищу освіту в такай спосіб, а прогнозується, що їх кількість найближчим часом збільшиться до $50 \%$. Найбільші та найпрестижніші університети світу передбачають можливість дистанційної або змішаної форми отримання вищої освіти на всіх рівнях, з'являються віртуальні університети [24]. 
Вагомим поштовхом до активізації пошуку шляхів впровадження технологій змішаного (а подекуди i чистого дистанційного) навчання та його активного використання в Україні стали карантинні та обмежувальні заходи, спрямовані на боротьбу із світовою пандемією 2020 року. Безперечно, постійне збільшення популярності МООС насамперед зумовлене світовими процесами глобалізації, інформатизації, поглибленням тенденцій доступності та масовості освіти. 3 іншого боку, невеликим каталізатором пришвидшення розвитку МООС як форми здобуття освіти стала епідемія коронавірусу. Так, за останній рік з'явилась велика кількість публікацій присвячених методиці організації навчального процесу з використанням технологій дистанційного навчання, проте в них не описано методику використання МООС при вивченні тих чи інших навчальних дисциплін у системі фахової підготовки майбутніх фахівців.

Зупиняючись на більш детальному розгляді шляхів та методики впровадження МOOC у навчальний процес у закладах вищої освіти України, варто наголосити на тому, що це $є$ найбільш актуальним для студентів, що навчаються за спеціальностями галузі знань 12 «Інформаційні технології», оскільки найбільш стрімко змінюються саме інформаційні технології, а тому фахівець у галузі IT має бути постійно в руслі цих змін, швидко на них реагувати, постійно поглиблювати свої професійні компетентності, займатися самовдосконаленням та саморозвитком. Основним акцентом у фаховій підготовці майбутніх ІT-фахівців має бути фундаментальна підготовка у відповідній предметній галузі, оскільки орієнтація на вивчення прикладних питань використання інформаційних технологій призводить до швидкого «старіння» знань майбутніх випускників. На нашу думку, використання МООС при підготовці майбутніх фахівців 3 інформаційних технологій дасть змогу студентам ознайомитися з можливими шляхами використання відкритих онлайн курсів у навчальному процесі та в подальшій професійній діяльності, сприятиме формуванню навичок самонавчання, самоосвіти, відкриє альтернативні шляхи опанування начальними дисциплінами, i, зрештою, форми здобуття вищої освіти.

У колективній монографії [25] С. Проскура, О. Кронда та С. Литвинова наводять результати опитування викладачів усієї країни (100 респондентів) та студентів бакалаврату (103 респонденти) за спеціальностями «Комп’ютерні науки» та «Системний аналіз» НТУУ «Київський політехнічний інститут імені І. Сікорського» щодо стану використання ними допоміжних позауніверситетських навчальних платформ (мається на увазі МООС), зручності їх використання в навчальній діяльності та наявності проблемних моментів під час роботи з ними. За результатами опитування було з'ясовано, що серед усього різноманіття МООС, частково використовуються для організації навчання чи самоосвіти лише платформи Coursera та Prometheus. Водночас зовсім незначна частина респондентів-викладачів (4 \% - Coursera та $17 \%$ - Prometheus) вказала, що активно використовує ці платформи в навчальному процесі. Разом з тим, 3 аналізу роботи не зрозуміло: в опитуванні брали участь викладачі, що забезпечують фахову підготовку 3 інформаційних технологій, чи всі викладачі, що забезпечують навчальний процес з відповідних спеціальностей.

Під час нашого дослідження було проведено аналіз можливостей використання МООС при вивченні фахових дисциплін майбутніми фахівцями 3 інформаційних технологій. У зв'язку з раптовим переходом на дистанційну форму навчання у березні 2020 року було з'ясовано педагогічні, технічні та методичні можливості використання MOОС при вивченні студентами інформатичних дисциплін. Експериментальне навчання проводилось на факультеті інформатики Національного педагогічного університету імені Михайла Драгоманова при вивченні дисциплін «Web-технології та 
web-дизайн» i «Web-програмування» студентами спеціальності «Комп’ютерні науки» та «Інформаційні системи і технології».

Для визначення можливих шляхів використання МООС при вивченні webтехнологій, webдизайну, webпрограмування та їх часткової інтеграції у відповідні навчальні курси, необхідно проаналізувати змістове наповнення відкритих онлайн курсів 3 даної тематики. Варто зазначити, що з початком пандемії різко змінилась статистика популярності відкритих онлайн курсів порівняно 3 минулим періодом. У [26] наведено список найпопулярніших категорій MOOC, на які активно реєструвалися користувачі в період до пандемії і під час неї (Рис. 2).
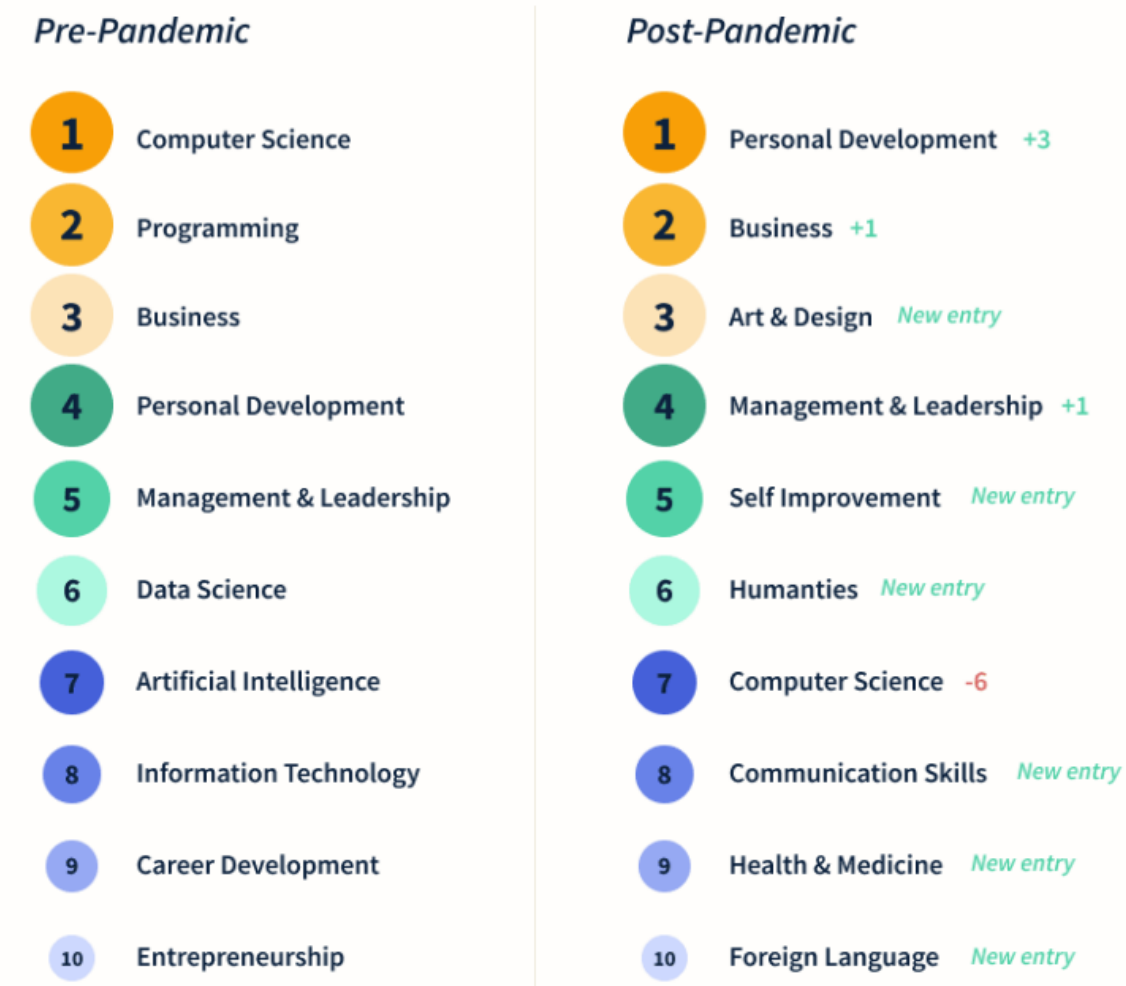

Рис. 2. Рейтинг популярності МООС до пандемії та під час неї

Легко пояснити збільшення популярності галузей знань, пов'язаних зі здоров'ям та медициною, гуманітарними дисциплінами, менеджментом, лідерством та бізнесом. Своєю чергою в умовах пандемії до першої десятки найпопулярніших онлайн курсів за галузями увійшла тільки одна, пов'язана 3 інформаційними технологіями комп'ютерні науки (Computer Science), тоді як раніше галузі, пов'язані 3 інформаційними технологіями, займали половину списку першої десятки (Computer Science, Programming, Data Science, Artificial Intelligence, Information Technology). Це пояснюється, на нашу думку, різкою зміною людських потреб та цінностей, змінами, що відбулись в освітній, соціальній та професійній сфері у зв'язку з пандемією та карантинними обмеженнями.

Найбільш популярними світовими МООС-платформами, що надають доступ до онлайн курсів є Coursera, edX, FutureLearn, Kadenze, Khan Academy, Udacity, Udemy, Codecademy. Серед українських платформ, на яких розміщені МООС, варто виокремити Prometheus, EdEra та Відкритий Університет Майдану. У таблиці 1 наведено результати проведеного нами порівняльного аналізу найбільш популярних світових платформ масових відкритих онлайн курсів. Так, більшість із них містять 
курси англійською мовою (у багатьох наявні субтитри іншими мовами), можливість отримати безкоштовний сертифікат не передбачена (за винятком деяких курсів на платформі Coursera), тривалість курсів від кількох тижнів до кількох місяців.

Таблиия 1

Порівняльна характеристика світових МООС

\begin{tabular}{|c|c|c|c|c|c|c|}
\hline \begin{tabular}{|r} 
Назва \\
платформи \\
Характеристика \\
\end{tabular} & Coursera & $e d X$ & FutureLearn & $\begin{array}{c}\text { Khan } \\
\text { Academy }\end{array}$ & Udacity & Udemy \\
\hline Реєстрації & Обов'язкова & Обов'язкова & Обов'язкова & $\begin{array}{c}\mathrm{He} \\
\text { обов'язкова }\end{array}$ & Обов'язкова & Обов'язкова \\
\hline $\begin{array}{l}\text { Підтримка мов на } \\
\text { курсах }\end{array}$ & \begin{tabular}{|c|} 
Англійська, \\
+субтитри \\
(multilang.)
\end{tabular} & $\begin{array}{c}\text { Переважно } \\
\text { англійська } \\
\text { та деякі } \\
\text { інші } \\
\end{array}$ & $\begin{array}{c}\text { Переважно } \\
\text { англійська } \\
\text { та деякі } \\
\text { інші } \\
\end{array}$ & $\begin{array}{l}\text { Англійська, } \\
\text { +субтитри } \\
\text { (multilang.) }\end{array}$ & $\begin{array}{l}\text { Англійська, } \\
\text { +субтитри } \\
\text { (multilang.) }\end{array}$ & $\begin{array}{c}\text { Переважно } \\
\text { англійська } \\
\text { та деякі } \\
\text { інші } \\
\end{array}$ \\
\hline$\overline{\text { Спос }}$ & \begin{tabular}{|c|} 
Онлайн, \\
iOS app, \\
Android app \\
\end{tabular} & $\begin{array}{c}\text { Онлайн, } \\
\text { iOS app, } \\
\text { Android app }\end{array}$ & $\begin{array}{c}\text { Онлайн через } \\
\text { браузер }\end{array}$ & $\begin{array}{c}\text { Онлайн, } \\
\text { iOS app, } \\
\text { Android app }\end{array}$ & $\begin{array}{c}\text { Онлайн через } \\
\text { браузер }\end{array}$ & $\begin{array}{c}\text { Онлайн, } \\
\text { iOS app, } \\
\text { Android app }\end{array}$ \\
\hline $\begin{array}{l}\text { Середня } \\
\text { тривалість курсів }\end{array}$ & 6 - 10 тижнів & 4-12 тижнів & 4 тижні & \begin{tabular}{|c|} 
Онлайн курси \\
та лекції у \\
форматі \\
YouTube відео
\end{tabular} & 4 - 6 тижнів & $\begin{array}{c}2-6 \text { годин } \\
\text { лекцій }\end{array}$ \\
\hline $\begin{array}{l}\text { Можливість } \\
\text { отримання } \\
\text { сертифікату }\end{array}$ & $\begin{array}{l}\text { Безкоштовні } \\
\text { сертифікати }\end{array}$ & $\begin{array}{l}\text { Від } 49 \$ \text { за } \\
\text { сертифікат }\end{array}$ & $\begin{array}{c}49 \text { \$ за } \\
\text { сертифікат }\end{array}$ & $\begin{array}{c}\text { Сертифікати } \\
\text { відсутні }\end{array}$ & $\begin{array}{c}1116 \text { \$ за всю } \\
\text { програму } \\
\text { (кілька курсів) }\end{array}$ & $\begin{array}{l}\text { Лише на } \\
\text { платних } \\
\text { курсах }\end{array}$ \\
\hline $\begin{array}{l}\text { Загальна кількість } \\
\text { курсів }\end{array}$ & $>5000$ & $\sim 3200$ & $\sim 1950$ & $\begin{array}{c}\text { } 70000 \\
\text { навчальних } \\
\text { відео, завдань } \\
\text { та тестів }\end{array}$ & $\begin{array}{c}188 \\
\text { безкоштовних } \\
\text { курсів }\end{array}$ & 130000 \\
\hline $\begin{array}{l}\text { Кількість курсів } 3 \\
\text { категорії «Web } \\
\text { Development» }\end{array}$ & 80 курсів & 14 курсів & 7 курсів & 8 курсів & \begin{tabular}{|c|}
17 \\
безкоштовних \\
курсів
\end{tabular} & $\begin{array}{c}8143 \text { курси } \\
\text { (928 - } \\
\text { безкоштовних) }\end{array}$ \\
\hline
\end{tabular}

Варто відзначити, що найбільші платформи МООС (таблиця 1) містять досить велику кількість онлайн курсів 3 webдизайну та wеbпрограмування, що відкриває широкі можливості до їх використання в структурі класичних навчальних дисциплін вищих навчальних закладів України. Частковим обмеженням щодо активного використання в структурі класичних дисциплін МООС може виступати лише проблема недостатнього рівня володіння студентами іноземними, зокрема англійською, мовами. Проте це питання може бути вирішене шляхом використання онлайн курсів, що містять українські МООС-платформи, або пошуком та використанням онлайн курсів відомих світових провайдерів МООС з субтитрами мовою, якою володіє студент.

Провівши аналіз курсів українських МООС-платформ (таблиця 2), варто зазначити, що 3 webтехнологій та webпрограмування $є$ тільки два відкритих курси: «Основи веб-розробки (HTML, CSS, JavaScript)» на платформі EdEra та «Основи Web UI розробки» на платформі Prometheus.

Незважаючи на те, що МООС - це відносно нове явище в сучасному освітньому середовищі, а особливо в системі освіти України, ми рекомендуємо частково впроваджувати їх у начальні дисципліни закладів вищої освіти. Для цього потрібно з'ясувати шляхи інтеграції МООС у структуру класичних навчальних дисциплін. Зробимо це на прикладі дисциплін «Web-технології та web-дизайн» i «Webпрограмування» для підготовки майбутніх фахівців з інформаційних технологій. 
Таблиия 2

\section{Порівняння онлайн курсів 3 wеbтехнологій на EdEra i Prometheus}

\begin{tabular}{|c|c|c|}
\hline $\begin{array}{c}\text { Характеристика } \\
\text { курсу }\end{array}$ & $\begin{array}{c}\text { Курс «Основи веб-розробки (HTML, CSS, } \\
\text { JavaScript)» на платформі EdEra }\end{array}$ & $\begin{array}{c}\text { Курс «Основи Web UI розробки» на } \\
\text { платформі Prometheus }\end{array}$ \\
\hline Тривалість курсу & Близько 30 годин & 5 тижнів \\
\hline $\begin{array}{l}\text { Безкоштовний } \\
\text { сертифікат }\end{array}$ & $\begin{array}{c}\text { Так, за умови успішного проходження } \\
\text { тестових завдань і набору мінімальної } \\
\text { кількості балів }\end{array}$ & $\begin{array}{c}\text { Так, за умови успішного } \\
\text { проходження тестових завдань і } \\
\text { набору мінімальної кількості балів }\end{array}$ \\
\hline $\begin{array}{l}\text { Змістове } \\
\text { наповнення курсу }\end{array}$ & $\begin{array}{l}\text { Модуль 1. Основи створення та стилізації } \\
\text { вебсторінок (Web, HTML та CSS). } \\
\text { Модуль 2. Деталі стилізації вебсторінок } \\
\text { (поглиблене вивчення CSS) } \\
\text { Модуль 3. Створення інтерактивних } \\
\text { вебсторінок з Javascript } \\
\text { Модуль 4. Елементи сучасної фронт-енд } \\
\text { розробки }\end{array}$ & $\begin{array}{l}\text { Модуль 1. Як працюють Інтернет та } \\
\text { веб браузери } \\
\text { Модуль 2. Середовища розробки. } \\
\text { Введення в НTML. } \\
\text { Модуль 3. Використання CSS } \\
\text { Модуль 4. Основи Јavascript } \\
\text { Модуль 5. DOM (Об'єктна Модель } \\
\text { Документа) }\end{array}$ \\
\hline
\end{tabular}

Відповідно до навчальних та робочих програм 3 дисциплін «Web-технології та web-дизайн» $\mathrm{i}$ «Web-програмування» під час їх вивчення використовуються такі види діяльності студентів: лекційні заняття, лабораторні заняття, самостійна робота студентів. На лекційних та лабораторних заняттях розглядаються фундаментальні теоретичні та практичні питання організації мережі Інтернет та місця wеbсторінок у ньому, основи верстки шеbсторінок засобами HTML та CSS, створення динамічних webcaйтів 3 використанням мов wеbпрограмування, публікації, просування та оптимізації webcaйтів. Саме на лабораторних заняттях відбувається формування в студентів фахових та спеціальних компетентностей у галузі wеbдизайну та wеbпрограмування.

На нашу думку, на лекційних заняттях не варто застосовувати MOOC, а проводити лекції у формі навчальної проблемної дискусії з аналізом розв'язання конкретних завдань 3 webдизайну та wеbпрограмування. Проте, у зв'язку з наявністю великою кількості МОOC-курсів 3 webтехнологій та зміщенням акцентів на якість саме практичної підготовки майбутніх фахівців, варто збільшити кількість годин на лабораторні заняття за рахунок лекційних годин.

3 метою урізноманітнення видів діяльності студентів на лабораторних заняттях, популяризації МООС, створення сприятливих умов для активізації пізнавальної діяльності студентів та формування навичок організації самостійної роботи ми пропонуємо студентам за бажанням замінити лабораторні роботи одного 3 навчальних модулів курсу на відповідний невеликий за обсягом МООС. У якості таких онлайн курсів можуть бути такі МООС, що відповідають назвам та змістовому наповненню модулів і за тривалістю не переважають 3 - 4 навчальні тижні.

У змісті навчальної дисципліни «Web-технології та web-дизайн» передбачене вивчення 5 змістових модулів. На вступному занятті під час знайомства зі структурою навчальної дисципліни студентам проводиться невелика презентація можливостей використання МООС і пропонується як альтернатива до вивчення та оцінювання одного з навчальних модулів курсу обрати і пройти один із запропонованих МООС (таблиця 3). За умови успішного завершення всього онлайн курсу (або його частини) студентам виставляється відповідна кількість балів за той чи інший змістовий модуль.

Як правило, безкоштовні МООС містять навчальні відео (або текстовий навчальний матеріал) та тестові завдання для перевірки теоретичних знань. Проте на багатьох масових відкритих онлайн курсах з комп’ютерних наук та інформаційних технологій передбачено можливість автоматичного тестування програмного коду, а тому їх можна використовувати для набуття і визначення рівня сформованості навичок, що стосуються практичної (фахової) підготовки майбутніх IT-фахівців. 
Таблиия 3

Альтернативні МОOC

\begin{tabular}{|c|c|c|}
\hline $\begin{array}{c}\text { Назва змістового } \\
\text { модуля }\end{array}$ & Назва МОOС & Посилання \\
\hline \multirow[b]{2}{*}{$\begin{array}{c}\text { Webтехнології та } \\
\text { глобальна мережа } \\
\text { Інтернет }\end{array}$} & $\begin{array}{l}\text { Introduction to Web } \\
\text { Development }\end{array}$ & $\begin{array}{l}\text { https://www.futurelearn.com/courses/introduction-to- } \\
\text { web-development }\end{array}$ \\
\hline & $\begin{array}{l}\text { Web Design: Strategy } \\
\text { and Information } \\
\text { Architecture } \\
\text { (coursera.org) }\end{array}$ & $\begin{array}{l}\text { https://www.classcentral.com/course/web-design- } \\
\text { strategy-12097 }\end{array}$ \\
\hline \multirow{3}{*}{$\begin{array}{c}\text { Створення та розмітка } \\
\text { webcторінок засобами } \\
\text { HTML }\end{array}$} & $\begin{array}{l}\text { Основи } \begin{array}{l}\text { Web } \\
\text { розробки }\end{array} 2020 \text { (1 та } 2 \\
\text { тиждень) }\end{array}$ & $\begin{array}{l}\text { https://courses.prometheus.org.ua/courses/course- } \\
\text { v1:LITS+114+2020_T3/course/ }\end{array}$ \\
\hline & $\begin{array}{l}\text { Основи в веб-розробки } \\
\text { (HTML, } \\
\text { JavaScript) }\end{array}$ & $\begin{array}{l}\text { https://courses.ed-era.com/courses/course- } \\
\text { v1:EDERA_BBF+WEB+2019/info }\end{array}$ \\
\hline & $\begin{array}{l}\text { Introduction to } \\
\text { HTML5 (coursera.org) }\end{array}$ & https://www.classcentral.com/course/introhtml-4307 \\
\hline \multirow{3}{*}{$\begin{array}{c}\text { Стилізація } \\
\text { webдокумента засобами } \\
\text { CSS }\end{array}$} & 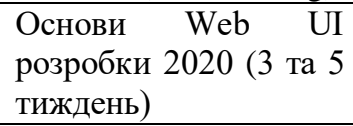 & $\begin{array}{l}\text { https://courses.prometheus.org.ua/courses/course- } \\
\text { v1:LITS+114+2020_T3/course/ }\end{array}$ \\
\hline & $\begin{array}{l}\text { Основи в веб-розробки } \\
\text { (HTML, } \\
\text { JavaScript) }\end{array}$ & $\begin{array}{l}\text { https://courses.ed-era.com/courses/course- } \\
\text { v1:EDERA_BBF+WEB+2019/info }\end{array}$ \\
\hline & $\begin{array}{l}\text { HTML5 and CSS } \\
\text { Fundamentals (edX) }\end{array}$ & $\begin{array}{l}\text { https://www.classcentral.com/course/edx-html5-and-css- } \\
\text { fundamentals-5764 }\end{array}$ \\
\hline \multirow{2}{*}{$\begin{array}{l}\text { Системи керування } \\
\text { вмістом webcторінок }\end{array}$} & $\begin{array}{l}\text { Web Development and } \\
\text { Design using } \\
\text { Wordpress (Kadenze) }\end{array}$ & $\begin{array}{l}\text { https://www.classcentral.com/course/kadenze-web- } \\
\text { development-and-design-using-wordpress-6408 }\end{array}$ \\
\hline & $\begin{array}{ll}\text { Web } & \text { Content } \\
\text { Management } & \end{array}$ & https://onlinecourses.swayam2.ac.in/cec21_lb01/preview \\
\hline \multirow{2}{*}{$\begin{array}{l}\text { Оптимізація та } \\
\text { просування сайту }\end{array}$} & $\begin{array}{l}\text { Website Performance } \\
\text { Optimization }\end{array}$ & $\begin{array}{l}\text { https://www.udacity.com/course/website-performance- } \\
\text { optimization--ud884 }\end{array}$ \\
\hline & $\begin{array}{l}\text { Optimizing a } \text { Website } \\
\text { for Google } \\
\text { (coursera.org) }\end{array}$ & $\begin{array}{l}\text { https://www.classcentral.com/course/optimizing-web- } \\
\text { search-5512 }\end{array}$ \\
\hline
\end{tabular}

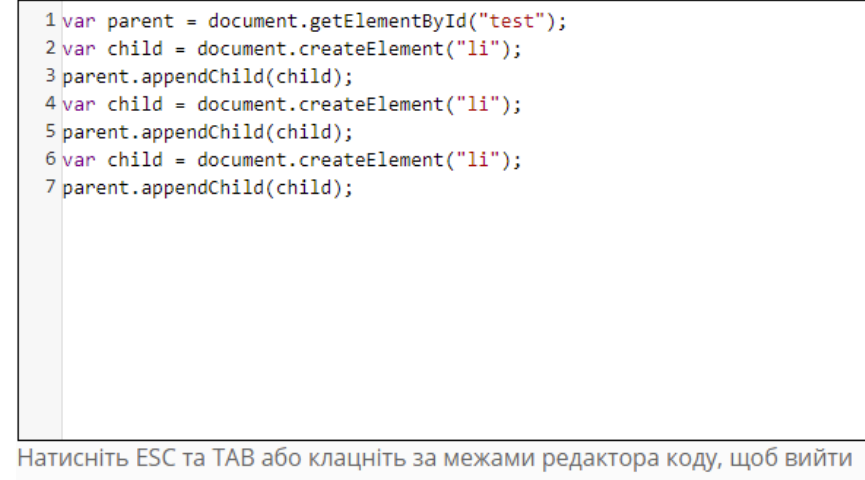


Значну частину годин під час вивчення вище зазначених навчальних дисциплін відведено на самостійну навчально-пізнавальну діяльність студентів, що передбачає підготовку до аудиторних занять, виконання завдань, що пропонуються на лекційних та лабораторних заняттях, захисту опорних конспектів, виконанні індивідуальних завдань, підготовці до модульного контролю тощо. Вважаємо за доцільне використовувати відкриті онлайн курси в якості самостійної роботи студентів для закріплення знань 3 пройдених тем або вивчення тих питань навчальної дисципліни, що не увійшли до змісту лекційних чи лабораторних занять.

Наприклад, при вивченні модуля «Створення та розмітка web-сторінок засобами HTML» можна запропонувати студентам в якості самостійної роботи ознайомитися 3 такими онлайн курсами, як-от «Images and Links in HTML» (https://www.coursera.org/projects/images-and-links-in-html) або «Tables and Forms in HTML» (https://www.coursera.org/projects/tables-and-forms-in-html) для поглиблення знань з відповідних питань навчального модуля. При вивченні модуля «Стилізація webдокументу засобами CSS» доцільним є проходження курсу «Style Images with CSS» (https://www.coursera.org/projects/style-images-with-css), що дасть змогу поглибити знання саме 3 оформлення зображень за допомогою CSS. Розширення знань та формування нових умінь студентів 3 webпрограмування може відбуватися при проходженні таких масових відкритих онлайн курсів: «Single Page Web Applications with AngularJS» (https://www.coursera.org/learn/single-page-web-apps-with-angularjs), «Web Application Development with JavaScript and MongoDB» (https://www.coursera.org/learn/web-application-development), «Full-Stack Web Development with React Specialization» (https://www.coursera.org/specializations/full-stackreact) тощо.

\section{Creating a Table}

Tables are defined by using the $<$ table $>$ tag.

Tables are divided into table rows with the $<$ tr> tag.

Table rows are divided into table columns (table data) with the $\langle\mathbf{t d}>$ tag.

Here is an example of a table with one row and three columns:

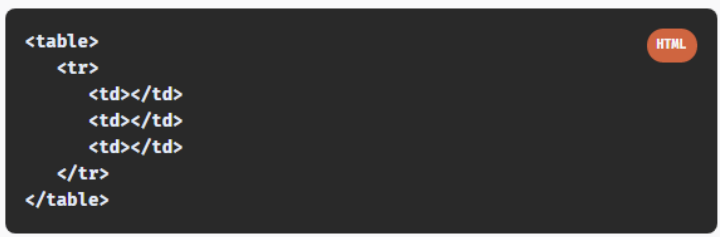

\section{Creating a Table}

What tag is used to create columns in a row?

tc

column

td

Table data tags $<\mathrm{td}>$ act as data containers within the table.

They can contain all sorts of HTML elements, such as text, images,

lists, other tables, and so on.

а) теоретичний матеріал

б) зразок тестового запитання

Pис. 4. Підготовка до тестування на ресурсі SoloLearn

Одним 3 важливих етапів вивчення навчальної дисципліни $\epsilon$ проміжний $\mathrm{i}$ підсумковий контроль рівня навчальних досягнень студентів. У курсах «Web-технології та web-дизайн» i «Web-програмування» він реалізований у вигляді тестування. Дуже вдалим для підготовки до тестування вважаємо pecypc SoloLearn 
(https://www.sololearn.com/) - безкоштовний webcaйт, що містить велику кількість курсів з програмування, реалізованих у вигляді коротких блоків теоретичного матеріалу 3 тестовим завданням до кожного 3 них. Тому даний ресурс був рекомендований студентам як засіб для підготовки до модульного та підсумкового контролю.

Ще одним важливим аспектом використання МООС є індивідуалізації вивчення навчальної дисципліни, що передбачає вибір студентами та вивчення тих відкритих онлайн курсів, що дають змогу забезпечити поглиблення та закріплення їх знань, умінь та навичок саме 3 тих питань, які їм здаються цікавими, перспективними, потрібними в їх майбутній професійній діяльності.

Враховуючи теоретичні засади та практичний досвід організації дистанційного навчання, швидкість збільшення кількості МООС та активність їх використання в освітній сфері, особливості організації навчання студентів у закладах вищої освіти в умовах пандемії, спираючись на результати проведеного педагогічного дослідження нами було розроблено модель інтеграції МООС у структуру навчальної дисципліни (рис. 5).

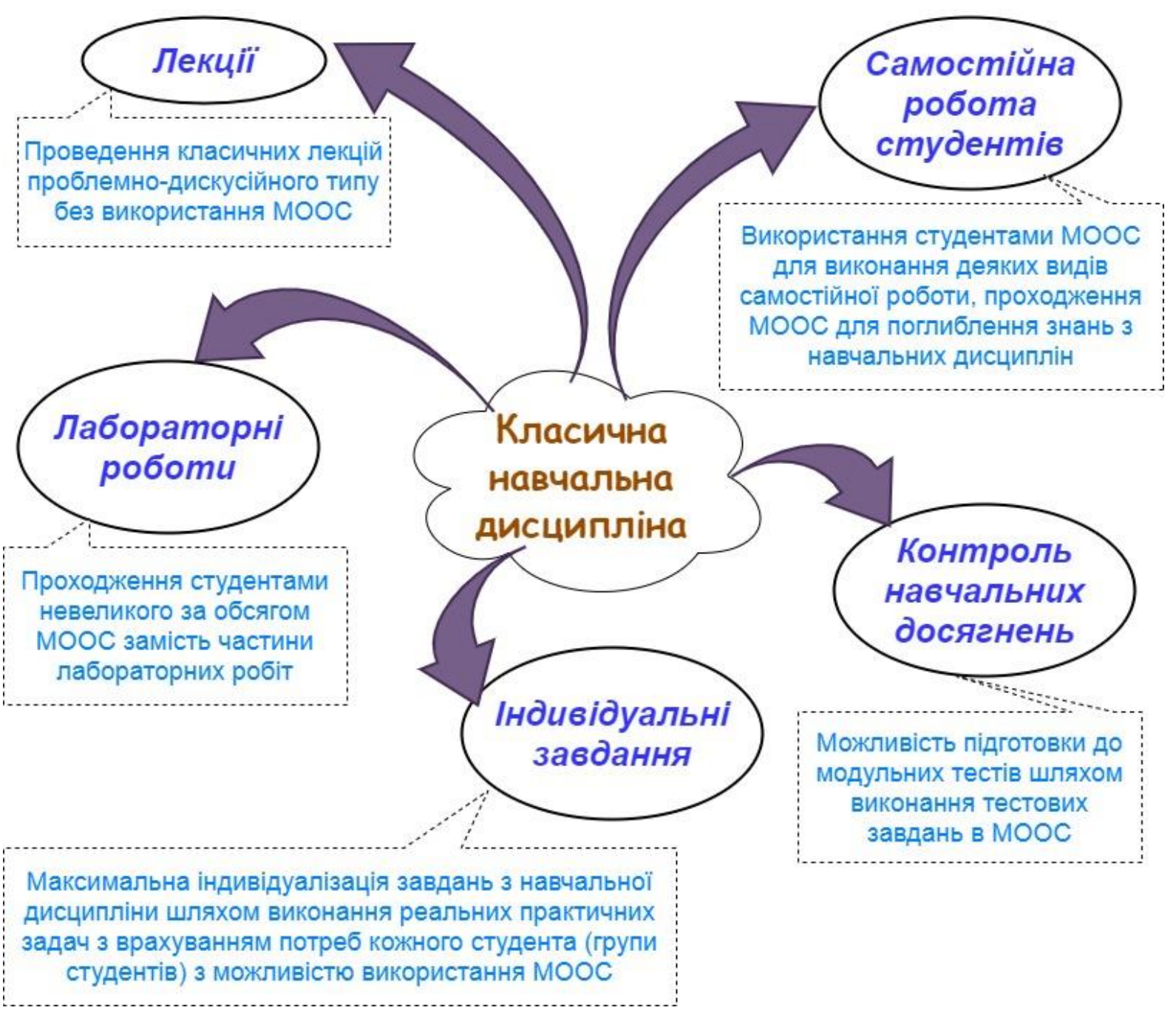

Рис. 5. Приклад інтегращиї МООС у структуру навчальної дисциилліни

В експериментальному дослідженні щодо використання МООС під час підготовки майбутніх фахівців з інформаційних технологій взяли участь 10 викладачів, що 
забезпечують фахову підготовку, та 40 студентів факультету інформатики Національного педагогічного університету імені Михайла Драгоманова: 14 студентів спеціальності «Комп'ютерні науки» у II семестрі 2019 - 2020 н.р., 6 студентів спеціальності «Інформаційні системи і технології» і 20 студентів спеціальності «Комп'ютерні науки» у I семестрі 2020 - 2021 н.р. Перед початком вивчення навчальних дисциплін «Web-технології та web-дизайн» i «Web-програмування» зі студентами проводилося вступне анкетування з метою з'ясування:

- рівня обізнаності студентів щодо можливих шляхів отримання нових знань, самоосвіти, здобуття дистанційної освіти;

- знань про можливості використання МООС для отримання освіти та досвіду студентів щодо їх використання.

Під час бесід з викладачами було з'ясовано, що МООС, на їх думку, є досить перспективним засобом активізації пізнавальної діяльності студентів та способом організації дистанційного навчання, хоча більшість викладачів (70 \%) не мають досвіду використання масових онлайн курсів у навчальному процесі. Аналіз результатів вступного анкетування студентів дав змогу зробити висновки про те, що більшість студентів $(77,5 \%)$ не обізнані в способах отримання дистанційної освіти, самонавчання. Водночас частина студентів чули про платформи, що містять МООС $(22,5 \%)$, але жодного разу там не реєструвалися і не проходили курс. I лише 17,5 \% студентів проходили масовий відкритий онлайн курс з інших навчальних дисциплін або для самоосвіти.

Після проведення вступного анкетування (https://forms.gle/uKpVr6tRnNPYZHDF7) студентам повідомлялось про зміст відповідного курсу, його структуру та про варіанти заміни окремого модуля курсу відповідним масовим онлайн курсом (для дисципліни «Web-технології та web-дизайн» варіанти замін наведені в таблиці 3), було окреслено можливі шляхи використання МООС для організації самостійної роботи студентів та підготовки до поточного та підсумкового контролю рівня навчальних досягнень.

У кінці навчального семестру студентам пропонувалось пройти фінальне анкетування (https://forms.gle/aC37DVVF6HkMXalp7), після аналізу результатів якого було з'ясовано, що після завершення експериментального навчання з використанням MOOC в межах зазначених дисциплін, частина студентів (40\%) зацікавилася і почала вивчення інших дисциплін на МООС, а 72,5 \% відповіли, що будуть надалі використовувати МООС для вивчення інших навчальних дисциплін або для самоосвіти та поглиблення знань.

Оскільки на факультеті інформатики вже досить тривалий час як засіб організації дистанційного доступу до навчальних матеріалів використовується LMS Moodle, то цікавою була думка респондентів щодо ефективності і доцільності його використання під час організації дистанційного навчання. Більшість студентів висловила думку про те, що розміщення матеріалів в LMS Moodle $\epsilon$ досить зручним, забезпечує швидкий доступ до лекційних матеріалів, завдань до лабораторних робіт та засобів діагностики успішності. Проте, на думку студентів, LMS Moodle не повинен бути єдиним засобом підтримки дистанційного навчання, а тому під час організації дистанційного чи змішаного навчання варто розглянути можливість використання інших засобів доступу до навчальних матеріалів, чатів, засобів відеоконференцій, МООС тощо.

Результати анкетування доводять, що для більшості студентів $(82,5 \%)$ MOOC $є$ новим способом здобуття освіти, вивчення нових навчальних дисциплін чи поглиблення вже наявних знань, проте досить цікавим i перспективним щодо організації самостійної роботи і дистанційного навчання. Отже, під час проведеного нами педагогічного експерименту було доведено доцільність використання МООС при 
вивченні фахових дисциплін студентами, що навчаються за спеціальностями 122 «Комп’ютерні науки» [27] та 126 «Інформаційні системи і технології» [28].

\section{4. ВИСНОВКИ ТА ПЕРСПЕКТИВИ ПОДАЛЬШИХ ДОСЛІДЖЕНЬ}

Одним 3 аспектів впровадження технологій МООС у систему вищої освіти України $є$ поєднання класичної очної системи навчання $з$ дистанційними технологіями (змішане навчання), зокрема з'ясування питань інтеграції МООС у структуру навчальних дисциплін та розроблення методики використання відкритих онлайн курсів у навчальному процесі. Сьогодні більшість закладів вищої освіти України вже мають досвід впровадження змішаної форми навчання, а в останній рік були змушені частково переходити на повністю дистанційні технології навчання. Отже, можна говорити, що всесвітня пандемія 2020 року активізувала процес впровадження дистанційного навчання в класичному його розумінні в середні та вищі навчальні заклади освіти України та всього світу.

У проведеному дослідженні доведено важливість залучення студентів саме ITспеціальностей до проходження МООС, оскільки розвиток інформаційних технологій відбувається дуже швидкими темпами i для того, щоб володіти сучасними, актуальними знаннями у сфері IT, потрібно постійно підвищувати свій рівень обізнаності, удосконалювати вміння та навички. Залучення студентів до проходження MOОС сприятиме, перш за все, формуванню в них навичок самоосвіти, розширить їх кругозір щодо способів здобуття знань у сучасному інформаційному суспільстві та дасть змогу використовувати масові відкриті онлайн курси в майбутній професійній діяльності для вдосконалення та поглиблення своїх професійних компетентностей, оволодіння новими технологіями, постійного самовдосконалення. 3 іншого боку, використання МООС дає змогу пройти онлайн курси, що розроблені викладачами провідних університетів світу, або під їх керівництвом стати членом мультинаціональної студентської групи та отримати сертифікат, що підтверджує успішне завершення курсу.

Із запропонованої в роботі моделі інтеграції МООС у структуру класичної навчальної дисципліни видно, що використовувати відкриті онлайн курси можна на різних етапах вивчення навчальних дисциплін у закладах вищої освіти: під час виконання лабораторних чи індивідуальних робіт, в процесі самостійної роботи студентів, підготовки до модульного чи підсумкового контролю. Проведений експеримент щодо впровадження МООС в процес підготовки майбутніх IT-фахівців доводить доцільність застосування МООС в навчальному процесі закладів вищої освіти, оскільки за результатами анкетування досить велика кількість студентів зацікавилася в проходженні MOOC також і з інших дисциплін, а в процесі навчання спостерігалась підвищена увага студентів саме до проходження МООС.

Незважаючи на всі переваги використання МООС у навчальному процесі, варто пам'ятати про те, що ступінь інтеграції MOOC у структуру навчальних дисциплін у закладах вищої освіти має бути незначним, контрольованим і педагогічно виваженим, оскільки надмірне перевантаження дисципліни відкритими онлайн курсами може призвести до перерозподілу уваги студентів від класичної навчальної дисципліни до онлайн курсів і зменшення зацікавленості у виконанні лабораторних робіт, передбачених робочою програмою навчальної дисципліни.

Невирішеними наразі залишаються питання, пов'язані 3 технічними, методичними, психолого-педагогічними та нормативними аспектами впровадження МООС у структуру класичних навчальних дисциплін закладів вищої освіти України. Водночас важливим $\epsilon$ проведення та статистичне опрацювання результатів 
всеукраїнського анкетування щодо доцільності та важливості використання масових відкритих онлайн курсів під час підготовки студентів вищих навальних закладів.

\section{СПИСОК ВИКОРИСТАНИХ ДЖЕРЕЛ}

[1] О. О. Андрєєв та ін. Педагогічні аспекти відкритого дистаниійного навчання (колективна монографія) . За ред. О.О. Андрєєва, В.М. Кухаренка. Харків, Україна: Міськдрук, 2013.

[2] В. М. Кухаренко та ін. Теорія та практика зміманого навчання (колективна монографія) . За ред. В.М. Кухаренка. Харків, Україна: Міськдрук, 2016.

[3] К. Л. Бугайчук. «Масовий відкритий дистанційний курс: поняття, особливості проведення та перспективи використання в навчальному процесі системи МВС», Інформаційні технології $i$ засоби навчання, Том 26, № 6, 2011. doi: https://doi.org/10.33407/ittl.v26i6.551.

[4] M. M. Berezytskyi, V.P. Oleksyuk «Massive Open Online Courses as a Stage in the Development of ELearning», Information Technologies and Learning Tools, 2016, Vol 56, no 6, p. 51 - 63. doi: https://doi.org/10.33407/itlt.v56i6.1479.

[5] I. В. Бацуровська, «Педагогічна класифікація масових відкритих дистанційних курсів», Освітологічний дискурс, Том 15, № 3. С. 108 - 120, 2016. doi: https://doi.org/10.28925/23125829.2016.3.10820.

[6] I. В. Бацуровська, «Масові відкриті дистанційні курси: інноваційна тенденція в освіті», Науковий вісник Миколаївського начіонального університету імені В.О. Сухомлинського. Серія : Педагогічні науки, № 1 . С. $31-34,2015$.

[7] I. В. Бацуровська, А. М. Джаландінова, «Історія розвитку масових відкритих он-лайн курсів в освіті», Актуальні проблеми державного управління, педагогіки та психології, Вип. 1. С. 63 - 66, 2015.

[8] Н. В. Морзе, О.П. Буйницька, Л.О. Варченко-Троценко, Створення сучасного електронного курсу в системі MOODLE. Кам'янець-Подільський, Україна: ПП Буйницький О.А, 2016.

[9] O. A. Samoilenko, «Distance Learning Through the Mooc Platforms», Professional Pedagogics, 2020, Vol 20, no 1, p. 104 - 108. doi: https://doi.org/10.32835/2707-3092.2020.20.104-108.

[10] J. Valverde-Berrocoso, M. del C. Garrido-Arroyo, C. Burgos-Videla and M.B. Morales-Cevallos, «Trends in Educational Research about E-Learning: A Systematic Literature Review (2009-2018)», Sustainability, Vol. 12, no. 12, p. 51 - 73, 2020. doi: https://doi.org/10.3390/su12125153

[11] A. A. Aldahdouh, A. J. Osório, «Planning to Design MOOC? Think First!», The Online Journal of Distance Education and E-Learning, Vol. 4, no 2, p. 47 - 57, 2016. [Online]. Available: https://files.eric.ed.gov/fulltext/ED572897.pdf. Accessed on: Jan. 19, 2021.

[12] A. McAuley, B. Stewart, G. Siemens, D. Cormier, The MOOC Model for Digital Practice, University of Prince Edward Island, 2010.

[13] Rebecca Bennett, Mike Kent, Massive Open Online Courses and Higher Education: What Went Right, What Went Wrong and Where to Next? London: Routledge, 2017.

[14] Nicholas Fair, Lisa Harris, Manuel León-Urrutia, «Enhancing the Student Experience: Integrating MOOCs into Campus-Based Modules», Trends and Good Practices in Research and Teaching, no 1, 2019. doi: https://doi.org/10.36006/16184-08.

[15] Peter G. M. de Jong, James D. Pickering, Renée A. Hendriks, Bronwen J. Swinnerton, Fereshte Goshtasbpour \& Marlies E.J. Reinders, «Twelve tips for integrating massive open online course content into classroom teaching», Medical Teacher, Vol.42, no 4, p. 393 - 397. 2019. doi: 10.1080/0142159X.2019.1571569.

[16] D. Andone, V. Mihaescu, «Blending MOOCs into Higher Education Courses-A Case Study», Learning With MOOCS (LWMOOCS), 2018, pp. 134 - 136. doi: 10.1109/LWMOOCS.2018.8534606.

[17] M. J. Israel, «Effectiveness of Integrating MOOCs in Traditional Classrooms for Undergraduate Students», The International Review of Research in Open and Distributed Learning, Vol. 16, no 5, 2015. doi: https://doi.org/10.19173/irrodl.v16i5.2222.

[18] A. Bralić, B. Divjak, «Integrating MOOCs in Traditionally Taught Courses: Achieving Learning Outcomes With Blended Learning», International Journal of Educational Technology in Higher Education, Vol. 15, no 2, 2018. doi: https://doi.org/10.1186/s41239-017-0085-7

[19] Л. А. Ібрагімова, «Комплементарний аналіз використання потенціалу та можливостей відкритих он-лайн курсів в процесі вивчення дисципліни «Алгоритми та структура даних», Наукові записки Бердянського державного педагогічного університету: Педагогічні науки, № 1. С. 45 - 53, 2019.

[20] О. В. Струтинська, М. А. Умрик, «Впровадження технології МООС у процес підготовки майбутніх учителів інформатики», Науковий часопис НПУ імені М.П. Драгоманова. Серія № 2. Комп ’отерно-орієнтовані системи навчання. № 19 (26). С. 157 - 163, 2017. 
[21] O. V. Strutynska, M. A. Umryk, «The Use of MOOCs for Training of the Future Computer Science Teachers in Ukraine», E-learning \& Lifelong Learning, Vol. 8, p. 297 - 320, 2018.

[22] W. Al-Rahmi, A. Aldraiweesh, N. Yahaya, Y. Kamin, A. Zeki, «Massive Open Online Courses (MOOCs): Data on Higher Education», Data in Brief, Vol. 22, p. 118 - 125, 2019. doi: https://doi.org/10.1016/j.dib.2018.11.139.

[23] Shah Dhawal, «By The Numbers: MOOCs in 2020». [Online]. Available: https://www.classcentral.com/report/mooc-stats-2020/. Accessed on: January 22, 2021.

[24] Т. О. Ярошенко, «Дистанційне навчання в системі вищої освіти: сучасні тенденції», Інженерні та освітні технології. Том 7, № 4, С. 8 - 21, 2019. doi: https://doi.org/10.30929/23079770.2019.07.04.01.

[25] В. М. Кухаренко, В. В. Бондаренко, Екстрене дистанційне навчання в Україні (колективна монографія) / За ред. В.М. Кухаренка, В.В. Бондаренка. Харків, Україна: КП «Міська друкарня», 2020.

[26] Shah Dhawal, «The Second Year of The MOOC: A Review of MOOC Stats and Trends in 2020», [Електронний ресурс]. Доступно: https://www.classcentral.com/report/the-second-year-of-the-mooc/. Дата звернення: Січень 22, 2021.

[27] Стандарт вищої освіти України за спеціальністю 122 «Комп’ютерні науки» для першого (бакалаврського) рівня вищої освіти. [Електронний ресурс]. Доступно: https://mon.gov.ua/storage/app/media/vishcha-osvita/zatverdzeni\%20standarty/2019/07/ 12/ 122kompyuterni-nauki-bakalavr.pdf. Дата звернення: Лют. 06, 2021.

[28] Стандарт вищої освіти України за спеціальністю 126 «Інформаційні системи і технології» для першого (бакалаврського) рівня вищої освіти. [Електронний ресурс]. Доступно: https://mon.gov.ua/storage/app/media/vishcha-osvita/ zatverdzeni\%20standarty/12/21/126-informatsiynisistemi-ta-tekhnologii-bakalavr.pdf. Дата звернення: Лют. 06, 2021.

Матеріал надійшов до редакиії 18.03.2021p.

\title{
ИСПОЛЬЗОВАНИЕ ОТКРЫТЫХ ОНЛАЙН КУРСОВ В УСЛОВИЯХ СМЕШАННОГО ОБУЧЕНИЯ БУДУЩИХ СПЕЦИАЛИСТОВ ПО ИНФОРМАЦИОННЫМ ТЕХНОЛОГИЯМ
}

\author{
Рамский Юрий Савиянович \\ доктор педагогических наук, профессор, заведующий кафедрой информационных технологий и \\ программирования \\ Национальный педагогический университет имени М.П. Драгоманова, г. Киев, Украина \\ ORCID ID 0000-0003-2296-0654 \\ y.s.ramsky@npu.edu.ua
}

\section{Твердохлеб Игорь Анатольевич}

кандидат педагогических наук, доцент кафедры информационных технологий и программирования Национальный педагогический университет имени М.П. Драгоманова, г. Киев, Украина.

ORCID ID 0000-0001-6301-0159

i.a.tverdokhlib@npu.edu.ua

\section{Ящик Александр Богданович}

кандидат педагогических наук, доцент кафедры компьютерных технологий

Тернопольский национальный педагогический университет имени Владимира Гнатюка, г. Тернополь, Украина

ORCID ID 0000-0002-8420-3336

SanyTNPU@tnpu.edu.ua

\section{Рамский Андрей Юрьевич}

доктор экономических наук, профессор, профессор кафедры финансов и экономики Киевский университет имени Бориса Гринченко, г. Киев, Украина ORCID ID 0000-0001-7368-697X

a.ramskyi@kubg.edu.ua

Аннотация. В работе рассмотрена методика использования массовых открытых онлайн курсов (МООС) в процессе подготовки будущих специалистов по информационным 
технологиям, доказана важность привлечения студентов к использованию открытых онлайн курсов как средства для самообразования и саморазвития. Использование МООС в учебной деятельности студентов информатических специальностей позволяет им постоянно обновлять свои знания в эпоху быстро меняющихся информационных технологий, углублять свои умения и навыки по специальным дисциплинам, и, наконец, «пройти» курсы, разработанные преподавателями ведущих университетов мира. В рамках исследования был проведен сравнительный анализ самых популярных МООС-платформ, осуществлен подбор онлайн курсов, которые целесообразно было бы использовать в процессе изучения студентами дисциплин «Web-технологии и web-дизайн» и «Webпрограммирование». Учитывая теоретические основы и практический опыт организации дистанционного и смешанного обучения разработана модель интеграции МООС в структуру классической учебной дисциплины (описаны способы использования МООС при выполнении лабораторных, индивидуальных работ, в процессе самостоятельной работы студентов, их подготовки к модульному или итоговому контролю), которая может использоваться не только для подготовки студентов, обучающихся по специальностям отрасли знаний 12 «Информационные технологии», но и для других студентов высших учебных заведений Украины. На основании предложенной модели интеграции описано методику использования МООС в процессе специальной подготовки будущих ИТспециалистов, методику организации и проведения педагогического исследования, приведены его результаты. В ходе проведенного исследования было выяснено, что педагогически взвешенное внедрение в учебный процесс МООС способствует формированию у студентов навыков самообразования, совершенствованию и углублению профессиональных компетенций, открывает перед ними альтернативные пути получения высшего образования.

Ключевые слова: дистанционное обучение; смешанное обучение; массовые открытые онлайн курсы; информационные технологии.

\title{
THE USE OF OPEN ONLINE COURSES IN A BLENDED LEARNING ENVIRONMENT IN THE TRAINING OF FUTURE INFORMATION TECHNOLOGY SPECIALISTS
}

\author{
Yurii S. Ramskyi \\ Doctor of Pedagogical Sciences, Professor \\ National Pedagogical Dragomanov University, Kyiv, Ukraine \\ ORCID ID 0000-0003-2296-0654 \\ y.s.ramsky@npu.edu.ua \\ Ihor A. Tverdokhlib \\ PhD of Pedagogical Sciences, Associate Professor \\ National Pedagogical Dragomanov University, Kyiv, Ukraine \\ ORCID ID 0000-0001-6301-0159 \\ i.a.tverdokhlib@npu.edu.ua
}

Oleksandr B. Yashchyk

PhD of Pedagogical Sciences, Associate Professor

Ternopil Volodymyr Hnatiuk National Pedagogical University, Ternopil, Ukraine

ORCID ID 0000-0002-8420-3336

SanyTNPU@tnpu.edu.ua

\author{
Andrii Y. Ramskyi \\ Doctor of Sciences (Economics), Professor, Professor of the Finance and Economics Department \\ Borys Grinchenko Kyiv University, Kyiv, Ukraine \\ ORCID ID 0000-0001-7368-697X \\ a.ramskyi@kubg.edu.ua
}

Abstract. The paper considers the methodology of using massive open online courses in the
process of training future information technology specialists. It proves the importance of attracting
students to use open online courses as a means for self-education and self-development. The use of 
MOOC in the educational activities of students of computer specialties allows them to constantly improve their knowledge in the era of rapidly changing information technologies, deepen their skills in professional disciplines, and, finally, complete courses developed by teachers of leading universities in the world. As a part of the study, comparative analysis of the most popular MOOC platforms was carried out. We selected online courses that would be appropriate to use in the process of studying such disciplines as "Web Technologies and Web Design" and "Web Programming". Taking into account the theoretical foundations and practical experience of organizing distance and mixed learning, a model for integrating the MOOC into the structure of the classical academic discipline is developed (methods of using MOOC during laboratory, individual work, in the process of independent students work, preparation for modular or final control), which can be used not only for training students studying in the specialties of the field of knowledge 12 "Information Technologies", but also for other students of higher educational institutions of Ukraine. Based on the suggested integration model the methodology of using MOOC in the process of professional training of future IT specialists is described, as well as the method of organizing and conducting pedagogical research and its results. In the course of the study, it was found out that the pedagogically balanced introduction of MOOC into the educational process contributes to the formation of students' self-education skills, improvement and deepening of professional competencies, and opens up alternative ways for them to obtain higher education.

Keywords: distance learning; blended learning; Massive Open Online Courses; information technologies.

\section{REFERENCES (TRANSLATED AND TRANSLITERATED)}

[1] O. O. Andrieiev et al. Pedagogical Aspects of Open Distance Learning (kolektyvna monohrafiya). Za red. O.O. Andrieieva, V.M. Kukharenka. Kharkiv, Ukraine: Miskdruk, 2013 (in Ukrainian).

[2] V. M. Kukharenko et al. Theory and Practice of Blended Learning (kolektyvna monohrafiya). Za red. V.M. Kukharenka. Kharkiv, Ukraine: Miskdruk, 2016 (in Ukrainian).

[3] K. L. Buhaichuk. «The Massive Open Distance Learning Course: the Concept, Features and Prospects of Educational Use of the MVS», Information Technologies and Learning Tools, vol. 26, no 6, 2011.doi: https://doi.org/10.33407/itlt.v26i6.551. (in Ukrainian).

[4] M. M. Berezytskyi, V. P. Oleksyuk «Massive Open Online Courses as a Stage in the Development of ELearning», Information Technologies and Learning Tools, 2016, vol 56, no 6, pp. 51 - 63. doi: https://doi.org/10.33407/itlt.v56i6.1479. (in English).

[5] I. V. Batsurovska, «Pedagogical Classification of Massive Open Distance Courses», Osvitolohichnyi dyskurs, vol. 15, no 3. pp. 108 - 120, 2016. doi: https://doi.org/10.28925/2312-5829.2016.3.10820. (in Ukrainian).

[6] I. V. Batsurovska, «Massive Open Distance Courses: an Innovative Trend in Education», Naukovyi visnyk Mykolaivskoho natsionalnoho universytetu imeni V.O. Sukhomlynskoho. Seriia : Pedahohichni nauky, vol. 1. pp. 31 - 34, 2015 (in Ukrainian).

[7] I. V. Batsurovska, A. M. Dzhalandinova, «History of the Development of Massive Open Online Courses in Education», Aktualni problemy derzhavnoho upravlinnia, pedahohiky ta psykholohii, vol. 1. pp. 63 66, 2015 (in Ukrainian).

[8] N. V. Morze, O. P. Buinytska, L. O. Varchenko-Trotsenko, Creating a Modern e-Course in the MOODLE System. Kamianets-Podilskyi, Ukraine: P. P. Buinytskyi O. A, 2016 (in Ukrainian).

[9] O. A. Samoilenko, «Distance Learning Through the Mooc Platforms», Professional Pedagogics, 2020, vol 20, no 1, pp. 104 - 108. doi: https://doi.org/10.32835/2707-3092.2020.20.104-108. (in English).

[10] J. Valverde-Berrocoso, M. del C. Garrido-Arroyo, C. Burgos-Videla and M.B. Morales-Cevallos, «Trends in Educational Research about E-Learning: A Systematic Literature Review (2009-2018)», Sustainability, vol. 12, no. 12, pp. 51 - 73, 2020. doi: https://doi.org/10.3390/su12125153. (in English).

[11] A. A. Aldahdouh, A. J. Osório, «Planning to Design MOOC? Think First!», The Online Journal of Distance Education and E-Learning, vol. 4, no 2, pp. 47 - 57, 2016. [Online]. Available: https://files.eric.ed.gov/fulltext/ED572897.pdf. Accessed: Jan. 19, 2021 (in English).

[12] A. McAuley, B. Stewart, G. Siemens, D. Cormier, The MOOC Model for Digital Practice, University of Prince Edward Island, 2010 (in English).

[13] Rebecca Bennett, Mike Kent, Massive Open Online Courses and Higher Education: What Went Right, What Went Wrong and Where to Next? London: Routledge, 2017 (in English). 
[14] Nicholas Fair, Lisa Harris, Manuel León-Urrutia, «Enhancing the Student Experience: Integrating MOOCs into Campus-Based Modules», Trends and Good Practices in Research and Teaching, no 1, 2019. doi: https://doi.org/10.36006/16184-08. (in English).

[15] Peter G. M. de Jong, James D. Pickering, Renée A. Hendriks, Bronwen J. Swinnerton, Fereshte Goshtasbpour \& Marlies E.J. Reinders, «Twelve tips for integrating massive open online course content into classroom teaching», Medical Teacher, vol. 42, no 4, pp. 393 - 397. 2019. doi: 10.1080/0142159X.2019.1571569. (in English).

[16] D. Andone, V. Mihaescu, «Blending MOOCs into Higher Education Courses-A Case Study», Learning With MOOCS (LWMOOCS), 2018, pp. 134 - 136. doi: 10.1109/LWMOOCS.2018.8534606. (in English).

[17] M. J. Israel, «Effectiveness of Integrating MOOCs in Traditional Classrooms for Undergraduate Students», The International Review of Research in Open and Distributed Learning, vol. 16, no 5, 2015. doi: https://doi.org/10.19173/irrodl.v16i5.2222. (in English).

[18] A. Bralić, B. Divjak, «Integrating MOOCs in Traditionally Taught Courses: Achieving Learning Outcomes With Blended Learning», International Journal of Educational Technology in Higher Education, vol. 15, no 2, 2018. doi: https://doi.org/10.1186/s41239-017-0085-7. (in English).

[19] L.A. Ibrahimova, «Complementary Analysis of the Use of the Potential and Opportunities of Open Online Courses in the Process of Studying the Discipline "Algorithms and Data Structure"», Naukovi zapysky Berdianskoho derzhavnoho pedahohichnoho universytetu: Pedahohichni nauky, vol. 1. pp. 45 53, 2019 (in Ukrainian).

[20] O. V. Strutynska, M. A. Umryk, «Introduction of the MOOC Technology in the Process of Training Future Computer Science Teachers», Naukovyi chasopys NPU imeni M.P. Drahomanova. Seriia № 2. Kompiuterno-oriientovani systemy navchannia. vol. 19 (26). pp. 157 - 163, 2017 (in Ukrainian).

[21] O. V. Strutynska, M. A. Umryk, «The Use of MOOCs for Training of the Future Computer Science Teachers in Ukraine», E-learning \& Lifelong Learning, vol. 8, pp. 297 - 320, 2018 (in English).

[22] W. Al-Rahmi, A. Aldraiweesh, N. Yahaya, Y. Kamin, A. Zeki, «Massive Open Online Courses (MOOCs): Data on Higher Education», Data in Brief, Vol. 22, p. 118 - 125, 2019. doi: https://doi.org/10.1016/j.dib.2018.11.139. (in English).

[23] Shah Dhawal, «By The Numbers: MOOCs in 2020». [Online]. Available: https://www.classcentral.com/report/mooc-stats-2020/. Accessed: January 22, 2021 (in English).

[24] T. O. Yaroshenko, «Distance Learning in the Higher Education System: Current Trends», Inzhenerni ta osvitni tekhnolohii. vol. 7, no 4, pp. 8 - 21, 2019, doi: https://doi.org/10.30929/2307-9770.2019.07.04.01. (in Ukrainian).

[25] V. M. Kukharenko, V. V. Bondarenko, Emergency distance learning in Ukraine (kolektyvna monohrafiya). Za red. V.M. Kukharenka, V.V. Bondarenka. Kharkiv, Ukraine: KP «Miska drukarnia», 2020 (in Ukrainian).

[26] Shah Dhawal, «The Second Year of The MOOC: A Review of MOOC Stats and Trends in 2020», [Online]. Available: https://www.classcentral.com/report/the-second-year-of-the-mooc/. Accessed: January 22, 2021 (in English).

[27] The standard of higher education of Ukraine in the specialty 122 "Computer Science" for the first (bachelor's) level of higher education. [Online]. Available: https://mon.gov.ua/storage/app/media/vishchaosvita/zatverdzeni\%20standarty/2019/07/ 12/ 122-kompyuterni-nauki-bakalavr.pdf. Accessed: Feb. 06, 2021 (in Ukrainian).

[28] The standard of higher education of Ukraine in the specialty 126 "Information systems and technologies" for the first (bachelor's) level of higher education. [Online]. Available: https://mon.gov.ua/storage/app/media/vishcha-osvita/zatverdzeni\%20standarty/12/21/ 126-informatsiynisistemi-ta-tekhnologii-bakalavr.pdf. Accessed: Feb. 06, 2021 (in Ukrainian).

\section{(cc) BY-NC-SA}

This work is licensed under Creative Commons Attribution-NonCommercial-ShareAlike 4.0 International License. 